\title{
Intra population diversity in Rhizocotonia bataticola causing dry root rot of chickpea (Cicer arietinum L.) in India
}

\author{
Mamta Sharma $^{1 \star \#}$, Raju Ghosh ${ }^{1 \#}$, Tilak R. Sharma ${ }^{2}$ and Suresh Pande ${ }^{1}$ \\ ${ }^{1}$ International Crops Research Institute for the Semi- Arid Tropics (ICRISAT), Patancheru 502324, \\ Andhra Pradesh, India. \\ ${ }^{2}$ National Research Centre on Plant Biotechnology, Indian Agricultural Research Institute, New Delhi 110012, India.
}

Accepted 10 September, 2012

Fifty isolates of dry root rot pathogen Rhizoctonia bataticola collected from different agro-climatic zones in India were evaluated for the degree of subdivision in isolates level. The isolates showed variability in pathogenicity test. Genetic characteristics were analyzed based on the sequence of the rDNA-internal transcribed spacer (ITS) region. The phylogenetic tree based on rDNA-ITS analysis showed that the maximum number of $R$. bataticola isolates were very diverse and did not depend on geographical origin. Both pathological and molecular data correlated each other and supported that the $R$. bataticola present in India were very diverse and independent to their origin.

Key words: Chickpea, internal transcribed spacer- restriction fragment length polymorphism (ITS-RFLP), internal transcribed spacer (ITS) region sequence, phylogenetic tree, rDNA.

\section{INTRODUCTION}

Chickpea (Cicer arietinum L.) is one of the major grain legumes grown worldwide. It is a rich source of protein (20 to $25 \%$ ) and also enriches soil fertility by biological nitrogen fixation (Zia-Ul-Haq et al., 2012). India is the largest producer of chickpea in the world and accounts for more than $68.6 \%$ of the total world production. According to 2008 to 2009 estimates, chickpea production was 7.06 million tonnes from about 7.89 million ha area in India alone as compared to World's chickpea production of 9.23 million tonnes (FAOSTAT, 2009).

\footnotetext{
${ }^{\star}$ Corresponding author. E-mail: m.sharma@cgiar.org. Tel: 040 30713071. Fax: 04030713074.

\# Authors contributed equally to this work.
}

Abbreviations: DRR, dry root rot; ITS, internal transcribed spacer; PDA, potato dextrose agar; RB, Rhizoctonia bataticola
Yield loss due to insects and diseases in chickpea ranges from 5 to $10 \%$ in temperate and 50 to $100 \%$ in tropical regions (Van Emden et al., 1988). Chickpea is susceptible to many diseases (Nene et al., 1984) and among them dry root rot (DRR) caused by Rhizoctonia bataticola [synonym-Macrophomina phaseolina (Tassi) Goid] is one of the major limitations in chickpea production causing 10 to $20 \%$ annual loss (Dhar and Chaudhary, 2001). With the drastic reduction of chickpea area in northern India and its quantum increase in hot, drier rainfed central and southern India, the dry root rot is emerging as the most destructive constraint to chickpea productivity and production. The disease is more prevalent between flowering and podding stages especially during hot (temp 30 to $35^{\circ} \mathrm{C}$ ) and dry (deficit soil moisture) environmental conditions. Rhizoctonia bataticola (RB) is a soil and seed-borne necrotrophic fungal pathogen that has a global distribution and can infect more than 284 plant species including monocot and dicot plant hosts (Farr et al., 1995). In contrast to the many pathogens favored by change to moisture 
conditions (Garrett et al., 2006), RB may become more problematic in agricultural areas where climate change results in longer drought periods and higher temperatures (Mihail, 1989, 1992).

Prolonged saprobiotic survival ability of this pathogen in soil makes chemical control and crop rotation ineffective. Cultivation of resistant varieties is an only economical approach for the management of DRR of chickpea, but only a few sources with low level of genetic resistance are available till date. However, commercial cultivars of chickpea with desired level of genetic resistance to DRR have not yet been developed (Pande et al., 2004). Therefore, the information regarding diversity among the populations of the pathogen would enhance the development and release of disease resistant chickpea cultivars. Different molecular methods such as amplified fragment length polymorphism (AFLP) (Vandemark et al., 2000; Mayek-Perez et al., 2001), random amplified polymorphic DNA (RAPD) (Almeida et al., 2003; Jana et al., 2003; Rajkumar and Kuruvinashetti, 2007) and restriction fragment length polymorphism (RFLP) (Almeida et al., 2003), have been used to reveal the genetic polymorphism within populations of $M$. phaseolina isolated from host crops other than chickpea. However, only one report regarding rDNA sequencing with six isolates infecting chickpea from India have been used to study the diversity of RB (Aghakhani and Dubey, 2009). No detailed study regarding diversity of $R$. bataticola with more number of isolates have been described yet.

Therefore, the present study was undertaken to determine the genetic diversity of RB isolates collected from various chickpea growing agro-climatic regions in India by evaluating and comparing rDNA-ITS.

\section{MATERIALS AND METHODS}

\section{Fungal isolate origin}

Total fifty isolates of $R$. bataticola were collected in different years (2004 to 2010) from different chickpea growing regions of India covering eight states including Uttar Pradesh, Rajasthan, Tamil Nadu, Andhra Pradesh, Madhya Pradesh, Delhi, Himachal Pradesh and Uttarakhand (Table 1). Isolation was made by plating surface sterilized $(0.8 \%$ sodium hypochlorite for $2 \mathrm{~min})$ pieces from DRR infected roots of the chickpea plants on potato dextrose agar (PDA) medium. Inoculated plates were incubated at $25 \pm 2^{\circ} \mathrm{C}$ for colony growth. The cultures were purified by single sclerotial isolation and on the basis of morphological characters (mycelium and sclerotia) the isolates were identified as $R$. bataticola (Briton-Jones, 1925; Ashby, 1927; Holliday, 1980). The cultures were maintained on PDA slant at $4^{\circ} \mathrm{C}$ for further study.

\section{Pathogenicity test}

Pathogenicity test for all the 50 isolates was performed in laboratory on a susceptible cultivar BG 212 by paper towel technique (Nene et al., 1981). Inoculum was prepared from the seven days old culture of RB grown on $100 \mathrm{ml}$ potato dextrose broth medium (PDB). The culture was grounded in blender by adding each fungal mat with
$50 \mathrm{ml}$ of sterile distilled water. Eight day old seedlings of BG 212 grown in sterilized sand were uprooted, washed under running water and were inoculated by dipping in the inoculum of RB for 2 to $3 \mathrm{~min}$. Inoculated seedlings were placed in a folded, moist blotting paper with the shoot left outside and placed in a tray. Trays containing blotter paper with inoculated seedlings were incubated at $35 \pm 1{ }^{\circ} \mathrm{C}$ with a 12 -h photoperiod and regularly moistened with sterile distilled water for seven days. Eight to ten seedlings were kept in each paper towel for each isolate. Each isolate was replicated thrice following completely randomized block design (CRBD). Uninoculated seedlings served as control. Disease severity for each isolate was recorded seven days after inoculation (DAl) based on 1 to 9 disease rating scale (Nene et al., 1981).

\section{Deoxyribonucleic acid (DNA) extraction}

All the 50 isolates were grown in PDB medium at $25 \pm 2^{\circ} \mathrm{C}$ for 8 days. Mycelia were harvested by filtering through Whatman filter Paper No. 1, washed repeatedly with distilled sterilized water to remove excess salts adhering to it. DNA extraction was based on the cetrimide tetradecyl trimethyl ammonium bromide (CTAB) method (Murray and Thompson, 1980). Mycelium (1 g) was crushed in liquid nitrogen and transferred into $7.5 \mathrm{ml}$ pre-warmed $\left(65^{\circ} \mathrm{C}\right)$ DNA extraction buffer [1 $\mathrm{M}$ Tris- $\mathrm{HCl}(\mathrm{pH} 8.0), 5 \mathrm{M} \mathrm{NaCl}, 0.5$ $M$ EDTA ( $\mathrm{pH} \mathrm{8.0)}$ and $2 \%$ CTAB], mixed well and incubated in a water bath at $65^{\circ} \mathrm{C}$ with gentle shaking for $45 \mathrm{~min}$. Equal volume of chloroform: isoamyl alcohol (24:1 v/v) was added and mixed gently to denature proteins and centrifuged at $12,857 \mathrm{~g}$ for $10 \mathrm{~min}$. DNA was precipitated with 0.6 volume of chilled ethanol and 0.1 volume of $3 \mathrm{M}$ sodium acetate ( $\mathrm{pH} 5.2)$ and centrifuged at $18,514 \mathrm{~g}$ for 15 min. The pellets were washed twice with chilled $70 \%$ ethanol, dried at room temperature, re-suspended in $100 \mu \mathrm{l}$ sterile TE $(10 \mathrm{mM}$ Tris- $\mathrm{HCl}$ buffer and $1 \mathrm{mM}$ EDTA-pH 8 ) and stored at $-20^{\circ} \mathrm{C}$ deep freezer. Isolated DNA was electrophorased in $1.0 \%$ agarose gels to check the quality and concentration.

\section{Sequencing of $r$ DNA- ITS region}

All the 50 isolates were selected for rDNA- ITS sequencing using ITS 1 and ITS 4 primer pair (White et al., 1990). The PCR reaction contained $50 \mathrm{ng}$ genomic DNA, 1X PCR buffer (Takara Bio Inc, Japan), $1.5 \mathrm{mM} \mathrm{MgCl}_{2}, 0.2 \mathrm{mM}$ dNTPs, $0.25 \mu \mathrm{M}$ of each primer and 1.0 unit PrimeSTAR® HS DNA Polymerase (Takara Bio Inc, Japan) in a $50-\mu \mathrm{L}$ reaction volume. The PCR program was: one cycle at $94^{\circ} \mathrm{C}$ for 2 min, 35 cycles of $94^{\circ} \mathrm{C}$ for $30 \mathrm{~s}, 55^{\circ} \mathrm{C}$ for $30 \mathrm{~s}$, and $72^{\circ} \mathrm{C}$ for $30 \mathrm{~s}$, and one cycle of $72^{\circ} \mathrm{C}$ for $5 \mathrm{~min}$, and then held at $4^{\circ} \mathrm{C}$. PCR amplicons were purified with a Wizard ${ }^{\circledR}$ SV Gel and PCR Clean up system (Promega, USA) according to the manufacturer protocol and then sequenced from commercial service (Xcelris Labs Limited, Ahmedabad).

\section{Genetic data analyses}

Pathogenicity was analysed through analysis of variance (ANOVA) and significant levels by the Genstat (GenStat Release 12.1) statistical programme. In pathogenicity tests, the disease severity was taken as dependent variable and the isolates as fixed factor.

Sequence identity matrix was generated using Bioedit Sequence Alignment Editor (version 5.0.9) (Hall, 1999). After multiple alignment, phylogenetic analysis was done in MEGA 4.0 software (Tamura et al., 2007) using the default parameters of one character-based algorithm. The bootstrapped consensus phylogenetic tree was generated for each of these algorithms with 1000 replication. To compare the ITS restriction fragment length polymorphism (ITS-RFLP) among the present isolates, restriction 
Table 1. Details of isolates of Rhizoctonia bataticola (synonym-Macrophomina phaseolina) used in the present study and dry root rot severity on chickpea cultivar BG 212.

\begin{tabular}{|c|c|c|c|}
\hline Isolate accession & Place of collection (state) & Year of collection & Disease severity* \\
\hline RB1 & Kanpur (Uttar Pradesh) & 2004 & 8.7 \\
\hline RB2 & Coimbatore (Tamil Nadu) & 2005 & 9.0 \\
\hline RB4 & ICRISAT (Andhra Pradesh) & 2007 & 9.0 \\
\hline RB6 & ICRISAT-BP10 (Andhra Pradesh) & 2008 & 9.0 \\
\hline RB7 & ICRISAT-BIL1 (Andhra Pradesh) & 2008 & 9.0 \\
\hline RB8 & ICRISAT-BUS3 (Andhra Pradesh) & 2008 & 8.7 \\
\hline RB10 & ICRISAT-BIL2 (Andhra Pradesh) & 2008 & 8.7 \\
\hline RB11 & ICRISAT-BIL2 (Andhra Pradesh) & 2008 & 9.0 \\
\hline RB12 & Pati (Andhra Pradesh) & 2008 & 9.0 \\
\hline RB14 & Jodhpur (Rajasthan) & 2008 & 4.3 \\
\hline RB15 & Jabalpur (Madhya Pradesh) & 2008 & 8.7 \\
\hline RB16 & Delhi (Delhi) & 2008 & 4.0 \\
\hline RB17 & Damoh (Madhya Pradesh) & 2009 & 9.0 \\
\hline RB19 & Damoh 2 (Madhya Pradesh) & 2009 & 9.0 \\
\hline RB24 & ICRISAT-BUS4 (Andhra Pradesh) & 2007 & 7.7 \\
\hline RB26 & ICRISAT-BIL2 (Andhra Pradesh) & 2007 & 8.8 \\
\hline RB31 & ICRISAT-BUS3 (Andhra Pradesh) & 2007 & 6.0 \\
\hline RB34 & ICRISAT-BR5D (Andhra Pradesh) & 2007 & 9.0 \\
\hline RB36 & ICRISAT-BR4F (Andhra Pradesh) & 2009 & 7.7 \\
\hline RB37 & ICRISAT-BP4 (Andhra Pradesh) & 2009 & 9.0 \\
\hline RB39 & ICRISAT-BM14 (Andhra Pradesh) & 2009 & 9.0 \\
\hline RB43 & ICRISAT-BW1A (Andhra Pradesh) & 2009 & 9.0 \\
\hline RB44 & ICRISAT-BIL1 (Andhra Pradesh) & 2009 & 9.0 \\
\hline RB45 & ICRISAT-BW3 (Andhra Pradesh) & 2009 & 9.0 \\
\hline RB46 & ICRISAT-BW4 (Andhra Pradesh) & 2009 & 9.0 \\
\hline RB47 & ICRISAT-BR4I (Andhra Pradesh) & 2009 & 9.0 \\
\hline RB49 & Jabalpur (Madhya Pradesh) & 2009 & 9.0 \\
\hline RB50 & Jabalpur 2 (Madhya Pradesh) & 2009 & 9.0 \\
\hline RB53 & Brampuri (Madhya Pradesh) & 2009 & 7.7 \\
\hline RB55 & Katni (Madhya Pradesh) & 2009 & 9.0 \\
\hline RB56 & JNKVV (Madhya Pradesh) & 2009 & 8.7 \\
\hline RB57 & Rewa (Madhya Pradesh) & 2009 & 9.0 \\
\hline RB58 & Satna (Madhya Pradesh) & 2009 & 8.7 \\
\hline RB59 & IIPR (Uttar Pradesh) & 2009 & 9.0 \\
\hline RB61 & Dhaulakuan (Himachal Pradesh) & 2009 & 7.3 \\
\hline RB62 & Pantnagar (Uttarakhand) & 2009 & 5.0 \\
\hline RB63 & Ranchi (Jharkhand) & 2009 & 7.3 \\
\hline RB66 & ICRISAT-BP3B (Andhra Pradesh) & 2010 & 8.0 \\
\hline RB67 & ICRISAT-BP3C (Andhra Pradesh) & 2010 & 9.0 \\
\hline RB69 & ICRISAT-BP8B (Andhra Pradesh) & 2010 & 9.0 \\
\hline RB72 & ICRISAT-BL4A (Andhra Pradesh) & 2010 & 9.0 \\
\hline RB73 & ICRISAT-BL4 (Andhra Pradesh) & 2010 & 9.0 \\
\hline RB74 & ICRISAT-BM13A (Andhra Pradesh) & 2010 & 9.0 \\
\hline RB78 & ICRISAT-BW2B (Andhra Pradesh) & 2010 & 7.7 \\
\hline RB80 & ICRISAT-BW4A (Andhra Pradesh) & 2010 & 8.0 \\
\hline RB83 & ICRISAT-BW8 (Andhra Pradesh) & 2010 & 9.0 \\
\hline
\end{tabular}


Table 1. Contd.

\begin{tabular}{llll}
\hline RB84 & ICRISAT-BIL1 (Andhra Pradesh) & 2010 & 9.0 \\
RB85 & ICRISAT-BIL1 (Andhra Pradesh) & 2010 & 8.3 \\
RB86 & ICRISAT-BIL1 (Andhra Pradesh) & 2010 & 9.0 \\
RB87 & ICRISAT-BIL3C (Andhra Pradesh) & 2010 & 9.0 \\
LSD $(p<0.001)$ & & & 1.13 \\
\hline
\end{tabular}

*1-9 disease rating scale for dry root rot disease , 1. No infection on roots- Asymptomatic, $>1$ and $<3$ Very few small lesions on roots- Resistant, $>3$ and $<5$ Lesions on roots clear but small; new roots free from infection - Moderately resistant $>5$ and $<7$ Lesions on roots many; new roots generally free from infection - Susceptible $>7$ or 9 Roots infected and completely discolored- Highly susceptible.

map was generated using NEBcutter V2.0 program (Vincze et al., 2003).

\section{RESULTS}

\section{Pathogenecity test}

All 50 isolates of the pathogen RB proved pathogenic on chickpea cultivar BG 212. The DRR disease severity ranged from 4 to 9 (on 1 to 9 scale). The effect of isolates on severity was significant $(p<0.001)($ Table 1$)$.

\section{Sequencing of $r$ DNA- ITS region}

To confirm the intra- population variability of $R$. bataticola isolates, the rDNA-ITS region of all the 50 isolates of $R B$ was amplified and sequenced. The 50 rDNA sequences were deposited in the GenBank database under the accession nos HQ392771- HQ392820. The size of the PCR products ranged from 533 to $604 \mathrm{bp}$. The ITS of ICRISAT isolate Rb26 (Andhra Pradesh) collected from BIL2 field in 2007 was largest (604 bp) in sequence length, whereas it was smallest (533 bp) in isolate RB45 from BW4A field of ICRISAT, collected in 2010. The phylogenetic tree constructed based on the nucleotide sequence similarity of these 50 isolates showed 38 to $100 \%$ sequence identity and clustered them into three major groups (Figure 1). The first major cluster (Gr I) contains 22 isolates from Uttar Pradesh, Andhra Pradesh, Madhya Pradesh, Himachal Pradesh, Rajasthan, Tamilnadu and Delhi, the second cluster (Gr II) consists of the 18 isolates collected from Andhra Pradesh, Madhya Pradesh, Uttar Pradesh and Jharkhand and the third minor clusters ( $\mathrm{Gr}$ III) contains remaining 10 RB isolates from Andhra Pradesh, Madhya Pradesh and Uttar Pradesh (Figure 1). There was no clear-cut phylogenetic tree, year of isolation and geographic origin relationship between clustering in the rDNA-ITS in of the tested isolates.

Restriction maps constructed by the NEBcutter program (Vincze et al., 2003), of the ITS-rDNA sequences from the present study selecting seven restriction enzymes (EcoRl, Taql, Hinfl, Mbol, MSPI, Notl and HaellI) revealed significant polymorphism (Table 2). Eco RI, Taql, Hinfl, Mbol and MSPI showed different digestion pattern but no variation for the other enzymes (Notl and HaellI) were found. Among the 50 isolates, 4 isolates collected from Madhya Pradesh [Rewa (RB57) and Katni (RB55)], Tamilnadu [Coimbatore (RB2)] and Uttar Pradesh [Kanpur (RB1)] gave different restriction patterns in NEB cutter. Based on rDNA-ITS restriction fragment length polymorphism pattern obtained with the seven restriction enzymes chosen, all $50 \mathrm{RB}$ isolates were grouped into four groups (Figure 2). A total of 46 isolates were grouped in the first major group (I). The second group consists of the two isolates of RB (II) and the two minor clusters contain remaining 1 isolate each.

\section{DISCUSSION}

Understanding the virulence and genetic diversity of the pathogen is an important prerequisite for developing and deploying varieties with durable resistance. Therefore, the present study was undertaken to assess the intra population diversity of isolates collected from different agro climatic regions of India.

All the isolates proved to be pathogenic on chickpea cultivar BG 212. The results revealed that while there was significant variation in the virulence of the pathogen, there was no clear pattern of distribution linked to the virulence of the isolates. In contrast to the present results, Beas-Fernandez et al. (2006) observed that pathogenic specialization of $M$. phaseolina was related to the geographic origin of the isolates. All the isolates tested in the present study caused susceptible reaction on cultivar BG 212, but they differed significantly in their degree of pathogenicity. The pathogenic and non pathogenic isolates were not concentrated in any one particular state/region.

The rDNA-ITS analyses performed on genomic DNA of 50 isolates of $R$. bataticola ( $M$. phaseolina) revealed the presence of high level of genetic diversity. The rDNA-ITS have the unique potential for providing information 
Table 2. Estimated DNA length of restriction sites of ITS-rDNA region for $R$. bataticola isolates from India.

\begin{tabular}{|c|c|c|}
\hline Isolates name & Restriction enzyme & Restriction sites \\
\hline \multirow{7}{*}{ Rewa } & EcoRI & 221 \\
\hline & Taq1 & $177,236,289$ \\
\hline & Haelll & 31,47 \\
\hline & Hinfl & 230,238 \\
\hline & Mbol & 158,466 \\
\hline & Mspl & 272,428 \\
\hline & Notl & 45 \\
\hline \multirow{7}{*}{ Katni } & EcoRI & 243 \\
\hline & Taq1 & $177,230,289$ \\
\hline & HaellI & 422,238 \\
\hline & Hinfl & $227,235,495$ \\
\hline & Mbol & 306,478 \\
\hline & Mspl & 38,194 \\
\hline & Notl & 420 \\
\hline \multirow{7}{*}{ Kanpur } & EcoRI & 243 \\
\hline & Taq1 & $177,230,289$ \\
\hline & Haelll & 422,438 \\
\hline & Hinfl & $227,235,495$ \\
\hline & Mbol & 306,478 \\
\hline & Mspl & 38,194 \\
\hline & Notl & 420 \\
\hline \multirow{7}{*}{ Coimbatore } & EcoRI & 221 \\
\hline & Taq1 & $177,236,289$ \\
\hline & Haelll & 31,47 \\
\hline & Hinfl & 230,238 \\
\hline & Mbol & 158,466 \\
\hline & Mspl & 272,428 \\
\hline & Notl & 45 \\
\hline \multirow{7}{*}{ Other isolates } & EcoRI & 222 \\
\hline & Taq1 & $178,237,290$ \\
\hline & Haelll & 31,47 \\
\hline & Hinfl & 231,239 \\
\hline & Mbol & 159,467 \\
\hline & Mspl & 273,429 \\
\hline & Notl & 45 \\
\hline
\end{tabular}

across an entire genome, while ITS-RFLP analysis can reveal variation only within small region of the genome. The isolates showed varied level of genetic similarity within a range of 38.0 to $100 \%$, indicating high level of variability among them. Phylogenetic tree constructed using rDNA-ITS indicated high level of variability among the isolates from different states as well as within a state. The existence of genetic diversity among the isolates from the same as well as different states might be due to movement of $R$. bataticola through germplasm exchange and importation of contaminated seeds and equipments, as well as by soil infected with sclerotia (Aghakhani and Dubey, 2009).

No relationship was found between rDNA-ITS groups and the geographical origin of the isolates. Earlier workers also tried to establish relationship between isolates of $M$. phaseolina obtained from other host crops and their hosts as well as to the geographical origin. 


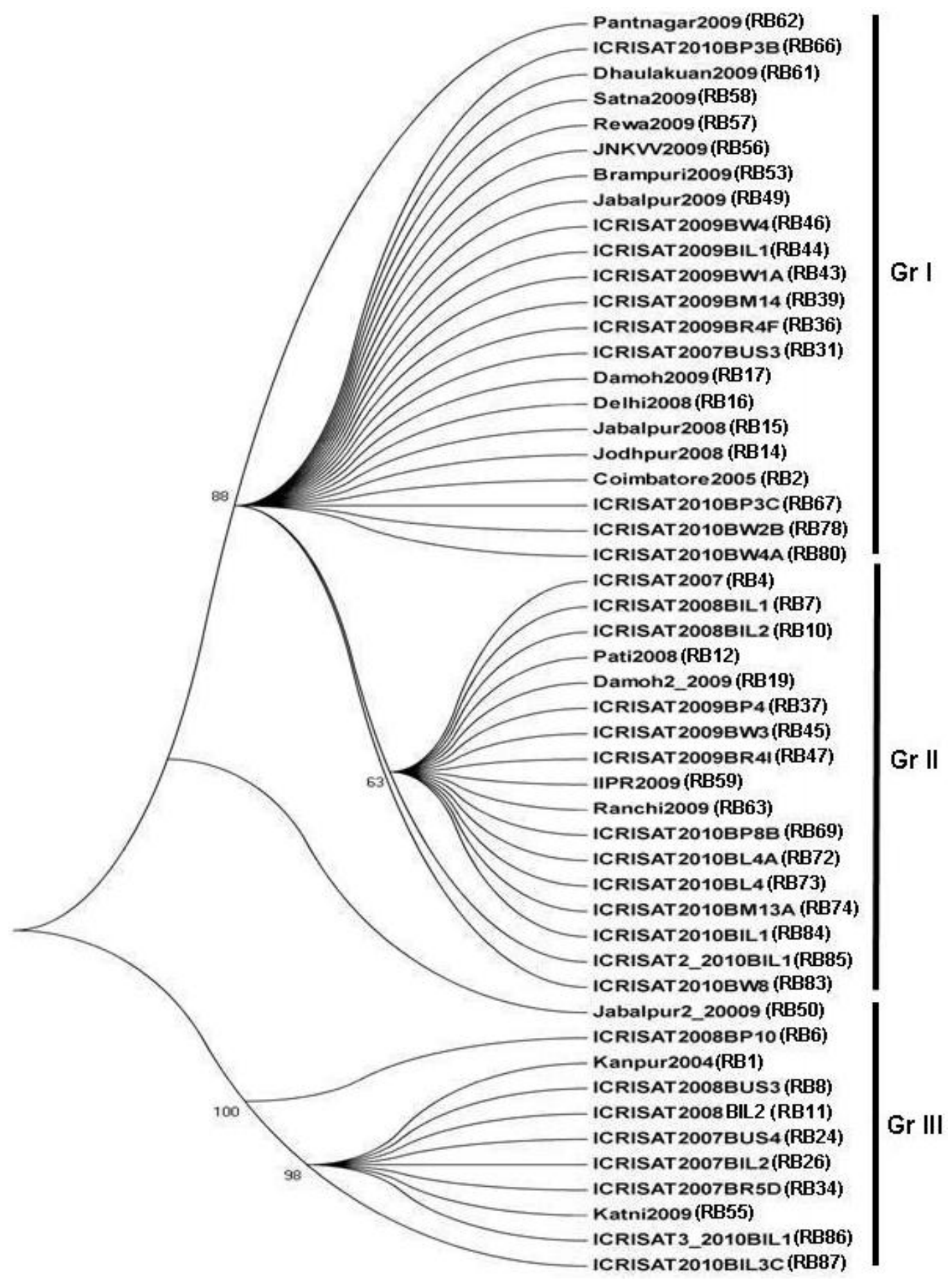

Figure 1. Phylogeny tree showing relationships among the fungal isolates based on their ITS sequences.

The presence of high level of variations among the isolates of $R$. bataticola in India may be attributed to variations in the climatic conditions and cropping patterns in different parts of the country, besides movement of the pathogen. Some of the isolates within a state showed similarity suggesting that these isolates may not evolve independently from each other and therefore, they may be considered as a part of the same ancestral population (Almeida et al., 2003). Nucleotide sequences of ITS regions of the isolates were also variable. The differences observed in the size of ITS regions of the isolates may be responsible for variations. The impact of $R$. bataticola on 


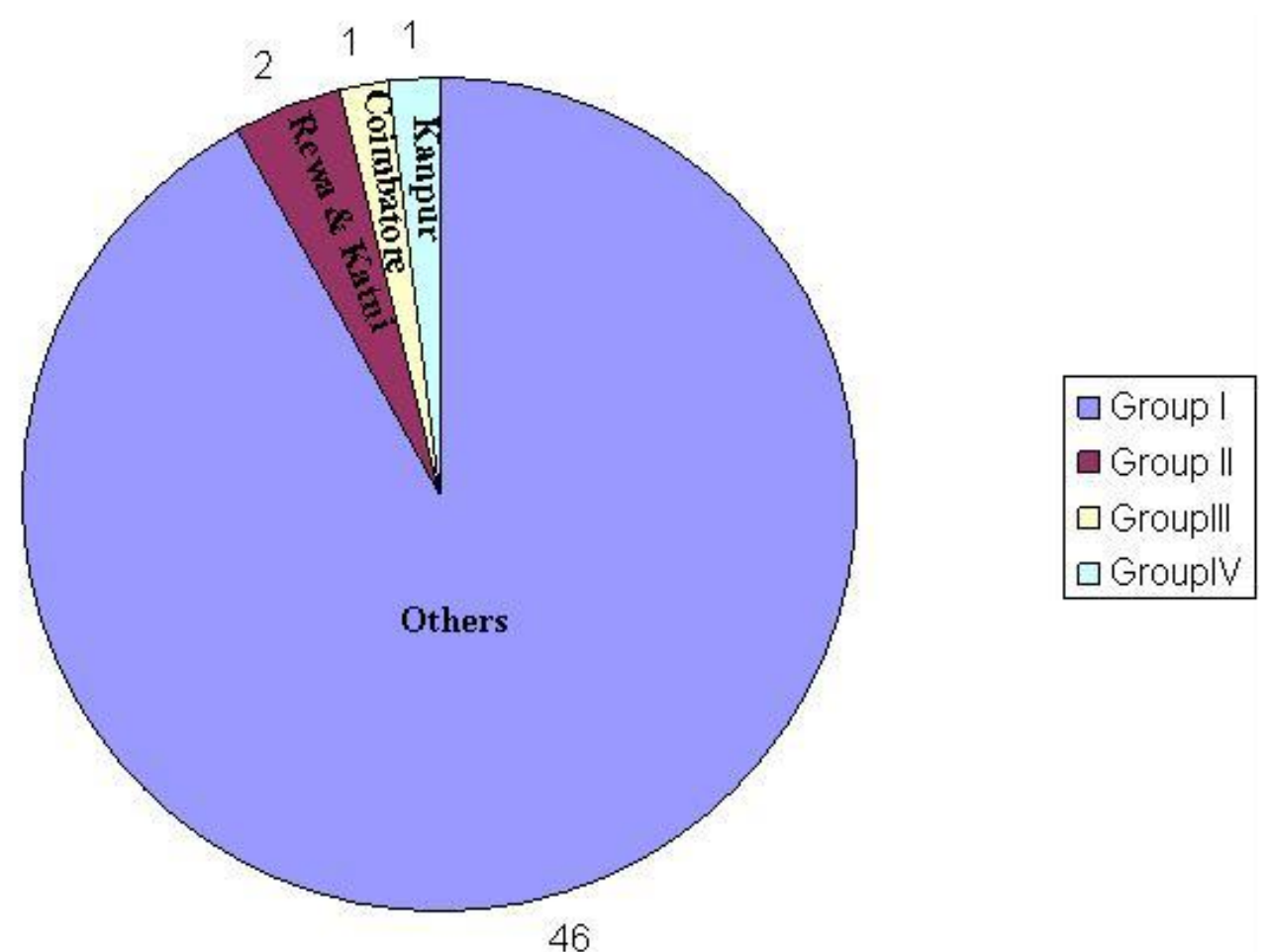

Figure 2. Pie chart demonstrating the probable grouping of $R$. bataticola isolates according to their restriction enzyme sites.

chickpea plant is little known, but to the extent that climate change increases heat and drought stress, chickpea plant should be more heavily affected by this pathogen.

The rDNA-RFLP analysis of $M$. phaseolina isolates collected from diverse geographical location revealed little variability within the species. The restriction endonucleases employed either produced identical patterns or had multiple cleavage sites giving small fragments that were difficult to analyze on agarose gel and also lack reproducibility (Lovic et al., 1995; Schmidt and Moreth, 1999). Similar results have been reported by other workers (Arora et al., 1996; Su et al., 2001). In a recent study some degree of polymorphism in restriction patterns of the ITS region, including part of $25 S$ rDNA, have been reported (Purkayastha et al., 2006; Aghakhani and Dubey, 2009). But, in the present study rDNA-RFLP generated by NEB cutter was also able to detect diversity even within a small number of chickpea isolates of $R$. bataticola. Restriction enzymes EcoRl, Taql, Haelll, Hinfl $\mathrm{Mbol}, \mathrm{Mspl}$ and Notl differentiated the isolates of the pathogen by showing different restriction sites. Isolates collected from Rewa and Coimbatore having the same restriction sites, placed them in a same restriction group, where as isolates collected from Katni and Kanpur having different restriction sites, placed them in a different restriction groups. Restriction analysis of the ITS region did not prove to be a suitable method for detecting variability among $R$. bataticola isolates, thus confirming the results of Su et al. (2001). The extensive diversity observed among the populations of $R$. bataticola in the present study with molecular markers could also be contributed by mutation in the pathogen in the field, seed and soil-borne nature of the pathogen, parasexuality and wide host range. Cultural practices as well as transport of seeds, soils and planting materials have contributed to the genetic diversity observed within a state.

Although rDNA is an extremely powerful chronometer for elucidating phylogenetic relationships, its high level of sequence conservation seems to limit its value for measuring and resolving close relationships. Hence, the results of the present findings clearly demonstrated that chickpea isolates of $R$. bataticola were highly variable. High level of variability in the populations of $R$. bataticola may be one of the causes of lack of resistance in the present commercial cultivars of chickpea. Thus, the information would also be utilized for the screening of genotypes of chickpea against group/area specific isolates to obtain resistance against variable populations of $R$. bataticola.

\section{REFERENCES}

Aghakhani M, Dubey SC (2009). Determination of genetic diversity among Indian isolates of Rhizoctonia bataticola causing dry root rot of chickpea. Antonie van Leeuwenhoek 96:607-619. 
Almeida AMR, Abdelnoor RV, Arias CAA, Carvalho VP, Jacoud DS, Marin SRR, Benato LC, Pinto MC, Carvalho CGP (2003). Genotypic Brazilian isolates of Macrophomina phaseolina revealed by RAPD. Fitopatologia Brasileira 28:279-285.

Arora DK, Hirsch PR, Kerry BR (1996). PCR-based molecular discrimination of Verticillium chlamydosporium isolates. Mycol. Res. 100:801-809.

Ashby SF (1927). Macrophomina phaseoli (Maubl) Com. Nov. the pycnidial stage of Rhizoctonia bataticola (Taub.) Butler. Trans. Br. Mycol. Soc. 12:141-142.

Beas-Fernandez1 R, DeSantiago A, Hernandez-Delgado N, MayekPerez S (2006). Characterization of Mexican and non-Mexican characteristics, pathogenicity on bean seeds and endoglucanase genes. Plant Pathol. 88:53-60.

Briton-Jones HR (1925). Mycological work in Egypt during the period 1920-1922. Egypt Ministry of Agriculture Technical and Sci. Bull. Cairo 49:129.

Dhar V, Chaudhary RG (2001). Disease resistance in pulse crop-current status and future approaches. In Nagarajan S, Singh DP (ed.), The role of resistance in intensive agriculture. New Delhi: Kalyani. p. 144157.

FAOSTAT (2009). Food and Agriculture Organization of the United Nations, Rome. http://faostat.fao.org

Farr DF, Bills GF, Chamuris GP, Rossman AY (1995). Fungi on Plants and Plant Products in the United States, 2nd ed. St Paul, MN: APS Press.

Garrett KA, Dendy SP, Frank EE, Rouse MN, Travers SE (2006). Climate change effects on plant disease: genomes to ecosystems. Annu. Rev. Phytopathol. 44:489-509.

Hall TA (1999). BioEdit: a user-friendly biological sequence alignment editor and analysis program for Windows95/98/NT. Nucleic Acids Symp. Ser. 41:95-98.

Holliday P (1980). Fungus diseases of tropical crops. Cambridge, NY10022: Cambridge university press. p. 607.

Jana TK, Sharma TR, Prasad RD, Arora DK (2003). Molecular characterization of Macrophomina phaseolina and Fusarium species by single primer RAPD technique. Microbiol. Res. 158:249-257.

Lovic BR, Martyn RD, Miller ME (1995). Sequence analysis of the ITS regions of rDNA in Monosporascus spp. reveals its potential for PCRmediated detection. Phytopathol. 85:655-661.

Mayek-Perez N, Lopez-Castaneda C, Gonzalez-Chavira M, GarciaEspinoa R, Acosta-Gallegos J, Martinez de la Vega OM, Simpson A (2001). Variability of mexican isolates of Macrophomina phaseolina based on pathogenesis and AFLP genotype. Physiol. Mol. Plant Path. 59:257-264.

Mihail JD (1989). Macrophomina phaseolina: spatio-temporal dynamics on inoculum and of disease in a highly susceptible crop. Phytopathology 79:848-855.

Mihail JD (1992). Macrophomina. In Singleton, LL, Mihail JD, Rush CM (eds), Methods for Research on Soilborne Phytopathogenic Fungi. St. Paul, Minnesota: APS Press pp. 134-136.
Murray MG, Thompson WF (1980). Rapid isolation of high molecular weight DNA. Nucleic Acids Res. 8:4321-4325.

Nene YL, Hawara MP, Reddy MV (1981). Chickpea disease resistance screening technique. ICRISAT Information Bull., 10:4-5.

Nene YL, Shiela VK, Sharma SB (1984). A world list of chickpea (Cicer arietinum) and pigeon pea (Cajanus cajan) pathogen. ICRISAT Pulse Pathol. Progress Report 32:19.

Pande S, Kumar KK, Rao JN (2004). Evaluation of chickpea lines for resistance to dry root rot caused by Rhizoctonia bataticola. The International Chickpea Pigeonpea Newsl. 11:37-38.

Purkayastha S, Kaur B, Chaudhury D (2006). Characterization of Macrophomina phaseolina, the charcoal rot pathogen of cluster bean, using conventional techniques and PCR based molecular markers. Plant Pathol. pp. 55-106.

Rajkumar BF, Kuruvinashetti MS (2007). Genetic variability of sorghum charcoal rot pathogen (Macrophomina phaseolina) assessed by random DNA markers. Plant Pathol. J. 23:45-50.

Schmidt O, Moreth U (1999). Identification of dry rot fungus, Serpula lacrymans and the wild Merulius, $S$. himantiodes, by amplified ribosomal restriction analysis (ARDRA). Holzforchung. 53:123-128.

Su G, Suh SO, Schneider RW, Russian JS (2001). Host specialization in the charcoal rot fungus, Macrophomina phaseolina. Phytopathol. 91:120-126.

Tamura K, Dudley J, Nei M, Kumar S (2007). MEGA4: Molecular Evolutionary Genetics Analysis (MEGA) software version 4.0. Mol. Biol. Evol. 24:1596-1599.

Van Emden HF, Ball SL, Rao MR (1988). Pest diseases and weed problems in pea, lentil and faba bean and chickpea. In Summerfield R. J. (ed.), World crops: cool season food legumes. Dordrecht: Kluwer. p. 519-534.

Vandemark G, Martinez O, Pecina V (2000). Assessment of genetic relationships among the isolates of Macrophomina phaseolina using simplified AFLP technique and two different methods of analysis. Mycol. 92:656-664.

Vincze T, Posfai J, Roberts RJ (2003). NEBcutter: a program to cleave DNA with restriction enzymes. Nucleic Acids Res. 3:3688-3691.

White TJ, Bruns T, Lee S, Talyor J (1990). Amplification and direct sequencing of fungal ribosomal RNA genes for phylogenetics. In Innis, MA, Gelfand DH, Sninisky JJ, White TJ (eds.), PCR protocols: a guide to methods and applications. San Diego: Academic Press $p$. 315-322.

Zia-Ul-Haq M, Khan BA, Landa P, Kutil Z, Ahmed S, Qayum M, Ahmad $S$ (2012). Platelet aggregatıon and antı-ınflammatory effects of garden pea, desı chıckpea and kabulı chıckpea. Acta Poloniea Pharm. 69:707-711. 